\title{
In vitro anti-cancer effect of Crataegus oxyacantha berry extract on hormone receptor positive and triple negative breast cancers via regulation of canonical Wnt signalling pathway
}

Salini K ( $\sim$ salinik1@hotmail.com) University of Madras - Guindy Campus https://orcid.org/0000-0002-3621-2879

Niranjali Devaraj Sivasithamparam

University of Madras - Guindy Campus https://orcid.org/0000-0001-6371-8552

\section{Research Article}

Keywords: ER+ve breast cancer, TNBC, Crataegus oxyacantha berry, canonical Wnt signalling pathway

Posted Date: August 3rd, 2021

DOI: https://doi.org/10.21203/rs.3.rs-768868/v1

License: (c) (1) This work is licensed under a Creative Commons Attribution 4.0 International License. Read Full License 


\title{
In vitro anti-cancer effect of Crataegus oxyacantha berry extract on hormone receptor positive and triple negative breast cancers via regulation of canonical Wnt signalling pathway
}

Salini Kombiyil ${ }^{\mathrm{a}}$ and Niranjali Devaraj Sivasithamparam ${ }^{\mathrm{a}}$

${ }^{a}$ Department of Biochemistry, University of Madras, Guindy campus, Chennai, 600025, India

Corresponding author: Niranjali Devaraj Sivasithamparam

E-mail ID: niranjali@yahoo.com; profniranjali@gmail.com

ORCID ID: Salini K- https://orcid.org/0000-0002-3621-2879

S. Niranjali Devaraj: https://orcid.org/0000-0001-6371-8552

\begin{abstract}
Breast cancer treatment strategy depends mainly on the receptor status. Our aim was to identify a herbal preparation, effective against breast cancer, irrespective of hormone sensitivity, and to understand its molecular mechanism. The rich antioxidant composition of Hawthorn (Crataegus oxyacantha) makes it a promising anti-cancer drug candidate. Polyphenol-rich methanolic extract of $C$. oxyacantha berry (M.Co) was found to be cytotoxic on hormone receptor positive (MCF-7) and triple negative (MDA-MB-231) breast cancer cell lines, at a dose $(75 \mu \mathrm{g} / \mathrm{ml})$ safe on normal cells. It could effectively inhibit tumor cell proliferation and arrest cell cycle at G1/S transition in both cell lines. Molecular targets were selected from different levels of canonical Wnt signalling pathway (such as autocrine and antagonistic ligands, receptor, effector, cytoplasmic components, downstream targets and pathway antagonist), since they are frequently found dysregulated in all breast cancers and their aberrant activation is associated with cancer stem cell expansion. M.Co could significantly downregulate the expression of Wnt pathway agonists and upregulate that of Wnt antagonists at transcriptional and translational levels, in both cell lines. To conclude, $C$. oxyacantha berry extract is effective against breast cancer irrespective of its hormone dependency and cancer growth inhibition at stem cell level can be expected.
\end{abstract}




\section{Key words:}

ER+ve breast cancer, TNBC, Crataegus oxyacantha berry, canonical Wnt signalling pathway

\section{Introduction}

Breast cancers are classified based on receptor status. This classification helps to decide on the type of therapy targeting the specific type of breast cancer. Estrogen receptor positive (ER+ve) breast cancer accounts for about 75\% [1] and triple negative breast cancers (TNBCs) account for 10-20\% of all types of breast cancers [2]. ER+ve and TNBCs have different clinical, pathological and molecular features. TNBCs are more aggressive, highly invasive, often produce distant metastases and require more intense treatment, show poorer prognosis and shorter duration of survival [3]. ER+ve breast cancers can be treated with tamoxifen, aromatase inhibitors, competitive estrogen antagonists and phytoestrogens like quercetin $[4,5]$. Current treatment strategies against TNBCs include chemotherapy agents, such as anthracyclines, taxanes, ixabepilone, and platinum agents, as well as selected biological agents [6]. Targetted therapy trials with anti-epidermal growth factor receptor (anti-EGFR), EGFR-Tyrosine kinase inhibitors are going on [7]. Recently approved targeted therapies for TNBCs include PARP inhibitors olaparib and talazoparib and checkpoint inhibitor, atezolizumab in combination with nab-paclitaxel [8]. A potent chemical/herbal preparation, which shows inhibitory effect on ER+ve and triple negative breast cancers, can be developed as an efficient drug against breast cancer, irrespective of its hormone sensitivity.

Hawthorn, our herb of interest, is best-known for treating heart conditions in western herbalism, Chinese medicine, Ayurveda and Homeopathy [9, 10]. Majorly studied as a cardioprotective agent [11-13], different preparations of hawthorn were also found to exhibit hypolipidemic $[14,15]$ anti-hyperglycemic $[16,17]$ anti-oxidant $[18,19]$ anti-inflammatory [20-22], cytotoxic [23-25], immunomodulatory [26], hepatoprotective [27] activities. Its 
chemopreventive effect on skin tumor formation in mouse epidermal cell line has also been reported [28]. Hawthorn constitutes a wide range of exciting phytochemicals that are responsible for its excellent pharmacological properties. Major phytocompounds include flavonoids, proanthocyanidins, phenolic carboxylic acids, cardiotonic amines, saponins, Vitamin C, Vitamin B etc. [9, 19, 29, 30]. The most commonly used species for medicinal purposes is Crataegus oxyacantha (common hawthorn) because of its wide availability and the high quantity of hawthorn's chemical constituents [31].

Wnt signalling studies have offered new insights in biomedical research, especially in tumorigenesis, cancer stem cells and drug discovery [32]. Its aberrant constitutive activation leads to expansion of stem cell lineages, promoting carcinogenesis [33]. Wnt signalling is associated with mammary gland development and tissue remodelling during pregnancy [34]. Wnt signalling through $\beta$-catenin i.e, the canonical Wnt signalling is the primary pathway for Wnt-mediated oncogenesis in the mammary gland [35, 36]. It is frequently found dysregulated in primary human breast tumors and breast cancer cell lines, regardless of the receptor status [37-39]. Different studies have demonstrated the inactivation of negative regulators and amplification of positive regulators of the Wnt signalling pathway in breast cancer $[36,40]$. Many plant polyphenols are known to employ regulation of $\mathrm{Wnt} / \beta$-catenin pathway as one of their anti-carcinogenic mechanisms [41-44]. Crude extracts rich in polyphenols are also found to inhibit canonical Wnt signalling pathway [45, 46].

Our aim was to evaluate the anti-carcinogenic potential of the methanolic extract of $C$. oxyacantha berry [M.Co] on breast cancer cell lines MCF-7 (ER+ve) and MDA-MB-231 (TNBC) and to study its effect on regulating molecular markers representing different levels of the canonical Wnt signalling pathway in both cell lines.

\section{Materials and Methods}




\section{Chemicals}

MTT (3-(4,5-Dimethylthiazol-2-yl)-2,5-Diphenyltetrazolium Bromide), TMB (3, 3', 5, 5'tetramethylbenzidine), PI (propidium iodide) and crystal violet from Sigma Aldrich (St. Louis, MO, USA); BSA, TRI reagent, random hexamer, deoxy nucleoside triphosphate (dNTPs), PCR Master Mix (2X), DNA 100bp ladder from Genei ${ }^{\mathrm{TM}}$ (India); Cell culture media and Fetal Bovine Serum (FBS) from Gibco life technologies (USA); trypsin and antibiotic solution from Himedia Laboratories (India); Vectashield from Vector Laboratories (Peterborough). Primers from Eurofins Genomics India Pvt.Ltd. (Bangalore, India), Primary antibodies from Abcam (USA) \& Cell Signalling Technology ${ }^{\circledR}$ (USA) and secondary antibodies from Thermo Fisher Scientific (USA). All other chemicals, solvents and reagents were from Sisco Research Laboratories Pvt. Ltd. (India) and SD Fine Chemicals (India).

\section{Extract preparation}

Dried berries of $C$. oxyacantha obtained from Hering Pharma (Pondichery, India), were washed, dried under shadow and powdered finely. Methanolic extract of C. oxyacantha berries (M.Co) was prepared from $10 \mathrm{~g}$ of powdered berry using $100 \mathrm{ml}$ of $70 \%$ methanol by

soxhlation at $65^{\circ} \mathrm{C}$ for $6 \mathrm{~h}$. Methanol was removed by rotary evaporation and the remaining aqueous portion was concentrated using lyophilization. Yield was calculated using the following formula (mass of the extract/mass of the dried raw plant material) X100.

\section{Cell line maintenance}

Mammary carcinoma cell lines - MCF-7 (RRID: CVCL_0031) and MDA-MB-231 (RRID: CVCL_0062) were obtained from National Centre for Cell Sciences (NCCS, Pune, India). Peripheral Blood Mononuclear Cells (PBMCs) were isolated from healthy volunteers using ficoll-hypaque [47]. MCF-7 cell lines were cultured in high glucose Dulbecco's Modified 
Eagle Medium (DMEM), MDA-MB-231 cells in Leibovitz L-15 medium and PBMCs in RPMI 1640 medium, all supplemented with 10\% FBS and 1X antibiotic, antimycotic solution

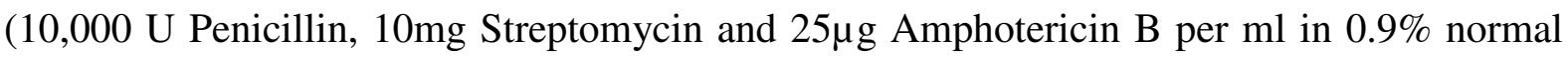
saline). MCF-7 cell lines and PBMCs were maintained at $37^{\circ} \mathrm{C}$, in presence of $5 \% \mathrm{CO}_{2}$ and MDA-MB-231 cell lines at $37^{\circ} \mathrm{C}$ in $\mathrm{CO}_{2}$ free environment. A split ratio of 1:2 was maintained for both cell lines. Medium was changed once in three days.

\section{Cytotoxicity assay}

MCF-7, MDA-MB-231 and PBMCs were seeded in a 96 well plate, at a cell density of 1x $10^{6}$ cells/ well and incubated with different concentrations of M.Co dissolved in DMSO, for $48 \mathrm{~h}$. Control and treated cells were then incubated with $10 \mu \mathrm{l}$ of MTT in dark for four hours at 37 ${ }^{\circ} \mathrm{C}$ and purple formazan crystals formed were dissolved in $100 \mu 1 \mathrm{DMSO}$. The plate was read on an ELISA plate reader (DNM-9602 microplate reader, Beijing Perlong New Technology Co., Ltd) at 570nm. Percentage viability was calculated by the formula [(mean absorbance of sample/ mean absorbance of control) $\times 100]$ and $\mathrm{IC}_{50}$ of M.Co was determined [48].

\section{Clonogenic assay}

MCF-7 and MDA-MB-231 cells were seeded in a six-well plate at a concentration of 1000 cells per well. After overnight incubation, cells were incubated in incomplete medium with or without M.Co, for $24 \mathrm{~h}$ and $48 \mathrm{~h}$. After that, the medium was removed and both control and treated cells were maintained in the growth medium for 1- 3 weeks with periodic media change. Once visible colonies were formed, the growth media was removed and washed gently with $1 \mathrm{X}$ phosphate buffered saline (PBS). The colonies were fixed with $1 \%$ formaldehyde for $10 \mathrm{~min}$ and stained in $0.05 \%$ crystal violet for $30 \mathrm{~min}$ [49]. Excess stain 
was washed off with PBS and the plate was allowed to dry. The stained colonies were then photographed.

\section{Cell cycle analysis}

MCF-7 and MDA-MB-231 cells were treated with M.Co for $24 \mathrm{~h}$ and $48 \mathrm{~h}$. Control and

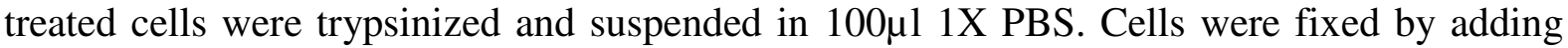
the suspension drop wise into $70 \%$ ice-cold ethanol and incubated at $4^{\circ} \mathrm{C}$ overnight. Cell pellet obtained by centrifugation at $1500 \mathrm{rpm}$ for $10 \mathrm{~min}$ was suspended in $500 \mu \mathrm{l}$ of the hypotonic staining solution (Sodium Citrate- 0.1gm, Triton-X-100- 0.3ml, PI - 0.01gm, RNase- $0.01 \mathrm{gm}$ in $100 \mathrm{ml}$ distilled water). It was then incubated in dark at $37^{\circ} \mathrm{C}$ for 30 minutes. Stain was then washed off and cells were suspended in $250 \mu 1$ of 1X PBS [50]. Cell cycle analysis was performed using FACS Calibur (BD Biosciences, USA). The data were analyzed using Multicycle software (Phoenix Flow Systems, USA).

\section{Molecular studies}

Targets for molecular studies were selected from different stages of canonical Wnt signalling pathway such as ligands [Wnt3A, Wnt5A]; receptor [phosphorylated lipoprotein receptorrelated protein-6 (pLRP6)]; cytoplasmic components [adenomatous polyposis coli (APC), phosphorylated glycogen synthase kinase $3 \beta$ (pGSK3 $\beta$ )]; effector molecule [ $\beta$ - catenin] and downstream targets- c-myc, cyclin D1, Peroxisome proliferator-activated receptor $\delta$ (PPAR $\delta)$, Cyclooxygenase-2 (COX-2)] and antagonist [E-cadherin].

\section{Semi quantitative reverse transcriptase (RT) PCR}

Control and M.Co treated MCF-7 and MDA-MB-231 cells were lysed in phenolguanidinium thiocyanate-based Tri Reagent. RNA was isolated from the lysate [51] and converted to cDNA [52]. Semi quantitative RT PCR was carried out [53] using the following

primers- $\beta$ - actin (F: 5' GATGAGATTGGCATGGCTTT 3'and R: 5' GAGAAGTGGGGTGGCTT 3'); 
APC (F: 5'AAACGAGCACAGCGAAGAAT 3'and R: 5' GCTTTCTGCCACTCCTTGA 3'); $\beta$ - catenin (F: 5' TAtgGaAgCtGAGgGagCCA 3'and R: 5' GgtCCATACCCAAGGCATCC 3'); cyclin- D1 (F: 5' CTCACACGCTTCCTCtCCAG 3'and R: 5' GgGaCtGTCAGTGGAGCAC 3'); c-myc (F: 5' ATGCCCCTCAACGTtAGCTT 3'and R: 5' GTGtgaCCGCAaCGTAGGA 3'); COX-2 (F: 5'

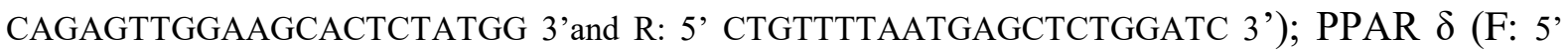
TTGAGCCCAAGTtCGAGTtTGCTG 3'and R: 5' ATtCTAGAGCCCGCAGAATGGTGT 3'). The RTPCR products were visualized on a $2 \%$ agarose gel stained with ethidium bromide, using UV transilluminator (Bioworld, Bengaluru, India).

\section{Immunocyto fluorescence staining}

MCF-7 and MDA-MB-231 cells were treated with M.Co for 48 h. Both control and treated cells were fixed in ice-cold methanol for $15 \mathrm{~min}$ at room temperature and permeabilized with $0.1 \%$ Triton-X-100 for 10 min. Non- specific binding was blocked with $0.5 \%$ Bovine Serum Albumin (BSA) for 45 min. Excess BSA was washed off and cells were incubated with primary antibodies [Rabbit polyclonal antibodies against Wnt 3A (Abcam Cat\# ab28472, RRID:AB_2215308), Wnt 5A (Abcam Cat\# ab229200, RRID:AB_2890100), pLRP 6 (CST cat\# 2568, RRID:AB_2139327), Cyclin D1 (CST Cat\# 2922, RRID:AB_2228523), pGSK3ß (Abcam cat \#ab107166, RRID:AB_11143750) and Mouse monoclonal antibodies against $\beta$ catenin (Abcam Cat\# ab22656, RRID:AB_447227) and E- cadherin (CST Cat\# 14472, RRID:AB_2728770)] diluted 1:150 with $0.5 \%$ BSA for $1 \mathrm{~h}$. Cells were washed in PBS and incubated with fluorescein isothiocyanate (FITC) conjugated secondary antibodies [antirabbit (Thermo Fisher Scientific Cat\# PA1-84922, RRID:AB_931578) and anti-mouse (Thermo Fisher Scientific Cat\# PA1-74422, RRID:AB_2540458)] at a dilution of 1:300 for 1 $\mathrm{h}$ in dark. Cells were counterstained in PI (1:1000 dilution) for 2 min, in dark, washed in PBS and mounted using Vectashield. Slides were viewed and photographed using Leica SP2 Confocal Microscope [54]. 


\section{Indirect Enzyme Linked Immunosorbent Assay (ELISA)}

MCF-7 and MDA-MB-231 cells were treated with M.Co for $48 \mathrm{~h}$. Both control and treated cells were harvested and lysed with lysis buffer [50mM Tris $(\mathrm{pH}-7.4), 150 \mathrm{mM} \mathrm{NaCl}, 1 \%$ Triton-X-100, 0.1\% SDS], freeze- thawed twice and centrifuged at 12,000 rpm for $20 \mathrm{~min}$. Supernatant was used to study the expression of Wnt3A and Wnt5A and lysate for that of pLRP-6, pGS3K $\beta, \beta$-catenin, cyclin- D1 and E-cadherin. Protein estimation was done by Lowry's method [55]. Samples were diluted to get a final protein concentration of $25 \mu \mathrm{g} / \mathrm{ml}$ in bicarbonate-carbonate coating buffer ( $\mathrm{pH}-9.6)$. The microtitre plate was then coated with 50 $\mu \mathrm{l}$ of the sample and incubated overnight at $4^{\circ} \mathrm{C}$. The remaining protein binding sites in the coated wells were blocked by incubation with $1 \%$ BSA for $2 \mathrm{~h}$ at room temperature. Primary antibodies, at a dilution of 1:500 in 1\% BSA, were added to the respective wells, incubated for $2 \mathrm{~h}$ at room temperature and excess antibody was washed off. The corresponding secondary antibodies [HRP conjugated anti-rabbit (Thermo Fisher Scientific Cat\# PA186143, RRID:AB_933610) and anti-mouse (Thermo Fisher Scientific Cat\# PA1-84406, RRID:AB_933651)] at a dilution of 1:1000 in PBS were added to the wells and incubated for $1 \mathrm{~h}$ at room temperature. The wells were then washed with PBS. $100 \mu \mathrm{l}$ of TMB reagent along with $10 \mu \mathrm{l}$ of $30 \% \mathrm{H}_{2} \mathrm{O}_{2}$ was added to the wells and incubated for $10-15 \mathrm{~min}$. After sufficient colour development, $100 \mu$ of stop solution $\left(2 \mathrm{~N} \mathrm{H}_{2} \mathrm{SO}_{4}\right)$ was added to the wells and kept for $5 \mathrm{~min}$. The absorbance was read at $450 \mathrm{~nm}$ [56].

\section{Statistical analysis}

All the results were expressed as mean \pm S.D for three experiments. Hypothesis testing method included one-way analysis of variance (ANOVA) followed by least significant difference (LSD) test. Significance was set at $\mathrm{P}<0.01$.

\section{Results and Discussions}




\section{Extract preparation}

Berries, in general, are rich in phenolic phytochemicals, which are responsible for their anticancer effects. Berry bioactives regulate sub-cellular signalling pathways of cancer cell proliferation, apoptosis and tumor angiogenesis [57, 58]. Hydro alcoholic extracts of hawthorn excel in antioxidant properties and pharmacological efficacy. A study showed that $70 \%$ methanol extracts from hawthorn had higher concentrations of polyphenols and exhibited good antioxidant properties [59]. So, it was decided to prepare M.Co with 70\% methanol. Soxhlet extraction was chosen since higher temperatures facilitate extraction of more phytocompounds. Yield of M.Co was found to be $20.8 \%$. HPLC analysis (data not shown) revealed a good polyphenol profile of M.Co as follows- catechin $(0.012 \mathrm{mg} / \mathrm{g})$, epicatechin $(0.412 \mathrm{mg} / \mathrm{g})$, catechin-o-gallate $(0.066 \mathrm{mg} / \mathrm{g})$, epicatechin-o-gallate $(0.082 \mathrm{mg} / \mathrm{g})$, quercetin $(0.032 \mathrm{mg} / \mathrm{g})$, ellagic acid $(0.252 \mathrm{mg} / \mathrm{g})$ and gallic acid $(5.3 \mathrm{mg} / \mathrm{g})$.

\section{Cytotoxicity assay}

Berry extracts are reported to inhibit breast cancers irrespective of its hormone dependency. To state a few examples, extracts from freeze-dried fruits of blueberry and strawberry were effective in inhibiting the growth of MCF-7 and T47-D, irrespective of estrogen dependence[60]. Grape seed extract could inhibit the growth of ER+ve and ER-ve breast cancer cell lines- MCF-7, MDA-MB-231 and MDA-MB-468 [61]. MTT assay, which measures cellular metabolism, is widely used for studying the cytotoxic, anti- tumor and antiproliferative effects of herbal extracts. PBMCs isolated from healthy human volunteers are used as normal cell control in cytotoxicity assays, to find out whether the drug affects normal cell metabolism also [62]. We observed that the DMSO concentration used to dissolve M.Co was non-toxic to MCF-7 and MDA-MB-231 cells. The $\mathrm{IC}_{50}$ of M.Co was found to be $75 \mu \mathrm{g} / \mathrm{ml}$ in both MCF-7 and MDA-MB-231 cell lines. In case of PBMCs, $\mathrm{IC}_{50}$ was found to 
be between $500 \mu \mathrm{g} / \mathrm{ml}$ and $750 \mu \mathrm{g} / \mathrm{ml}$ (Fig 1). This confirmed that M.Co is cytotoxic to breast cancer cell lines, regardless of their hormone dependency. Also, the M.Co concentration which was effective on breast cancer cells is safe on normal cells.

When cancer cells undergo apoptosis, upon drug treatment, marked changes occur in cell morphology. Cell shrinkage, rounding up and membrane blebbing due to breakdown of proteinaceous cytoskeleton by caspases; anoikis, i.e, detachment of monolayer adherent cells from their basal membrane resulting in floating cells are some of them [63]. Morphological changes caused by M.Co in MCF-7 and MDA-MB-231 cells, such as cell shrinkage, rounding up, anoikis and membrane blebbing, are clearly shown in Fig 2, thereby confirming its cytotoxic effect.

\section{Cell proliferation assay}

Clonogenic assay or colony formation assay is based on the ability of a single cell to proliferate into a colony and it essentially tests every cell in the population for its ability to undergo "unlimited" division [64]. Clonogenic assays (colony formation assay) are widely being used to determine the effect of cytotoxic drugs on different tumors, since it has shown reliable clinical prediction [65]. In the present study, crystal violet stained plates in Fig 3 clearly depict that MCF-7 and MDA-MB-231 control cells have prominent clonogenic property, which was reduced after $24 \mathrm{~h}$ of treatment with M.Co. The number and size of colonies were decreased significantly after $48 \mathrm{~h}$ of treatment with M.Co. Thus it can be concluded that M.Co can inhibit breast cancer cell proliferation, irrespective of its hormone dependence.

\section{Cell cycle analysis}


One reason for targeting the cell cycle in anticancer therapy is the high frequency of mutations of their key molecules in human malignancy [66]. Moreover, induction of cell cycle arrest in cancer cells leads to apoptosis, thus inhibiting their uncontrolled proliferation. Many cell cycle specific (CCS) drugs- including plant-derived compounds- are currently being used for cancer therapy. Phytocompounds have been reported to inhibit cell cycle at different stages. Vinca alkaloids (vincristine, vinblastin, vinorelbin and vindesin) blocked cancer cell cycle at the $M$ phase [67]. The flavonoid Silibinin induced cell-cycle arrest at G2/M transition in colon cancer [68]. Resveratrol could block the cell cycle in MCF-7 at S phase, but did not affect the cell cycle in MDA-MB-231 cells [69].

Flow cytometric analysis of MCF-7 and MDA-MB-231 cells treated with M.Co for $24 \mathrm{~h}$ and $48 \mathrm{~h}$ is displayed in Fig 4 . In case of both cell lines, the number of cells getting accumulated in Go/G1 phase had significantly increased after $48 \mathrm{~h}$ treatment with M.Co. A significant decrease in the number of cells entering $\mathrm{S}$ phase was observed after $24 \mathrm{~h}$, which was further reduced after $48 \mathrm{~h}$ treatment with M.Co. A corresponding increase in the number of cells entering apoptosis was observed after $24 \mathrm{~h}$ and $48 \mathrm{~h}$ treatment with M.Co, in both cell lines. This clearly suggests that M.Co could arrest G1/S transition of breast cancer cell lines, irrespective of its receptor status.

\section{Molecular studies}

Since canonical Wnt signalling is tightly controlled at multiple cellular levels, it offers ample targets for cancer drug development. Autocrine Wnt signalling is found to be responsible for the drug resistance of ER+ve breast cancer cell lines [70]. Also, aberrant Wnt/ $\beta$-catenin signalling is found to have a role in the proliferation and metastasis of TNBCs [39, 71]. This makes canonical Wnt pathway and its components the most attractive targets for developing effective breast cancer therapy irrespective of the hormone dependence. 
In brief, Wnt ligands (such as Wnt 3A) bind to low density lipoprotein receptor-related protein (LRP6) and transmembrane receptors of the Frizzled (Fz) family. In the absence of Wnt ligands, the key molecule $\beta$-catenin is marked for ubiquitination and proteasomal degradation, by a multi-protein $\beta$-catenin degradation complex, consisting of tumor suppressor APC, scaffold protein Axin, GSK-3 $\beta$ and casein kinase 1. Activation of receptors by Wnt ligand binding leads to phosphorylation of GSK-3 $\beta$, causing the dissociation of $\beta$ catenin degradation complex. This failure to degrade $\beta$-catenin, leads to the stabilization and accumulation of cytosolic $\beta$-catenin, which then gets translocated to the nucleus and activates Wnt target genes by binding to transcription factors of the T-cell factor and the lymphoid enhancing factor (TCF/LEF) family. A number of Wnt/ $\beta$-catenin target genes have been identified, which include those that regulate cell proliferation, embryonic development and tumor progression such as c- myc, cyclin D1, PPAR- $\delta, \mathrm{COX}-2$, Matrix metalloproteinases (MMP)-7, MMP-2, MMP-9, Axin-2, CD-44 etc [72]. Non-canonical ligand, Wnt-5a enhances $\beta$-catenin/E-cadherin complex formation via a $\mathrm{Ca}^{2+}$-dependent mechanism in human breast epithelial cells [73] and thereby antagonizes canonical Wnt signalling by inhibiting the downstream transcriptional activity of $\beta$-catenin [74].

A comprehensive expression analysis of Wnt signalling molecules in immortalized human mammary epithelial cells and six breast cancer cell lines (including ER+ve and TNBCs), showed that redundant expression of Wnt ligands such as Wnt3A, frizzled receptors, coreceptors and LEF/TCF transcription factors was maintained in breast cancer cell lines. In contrast, the expression of non-canonical Wnt pathway ligands WNT5A was usually down regulated [40]. Several studies have observed elevated level of nuclear and/or cytoplasmic $\beta$ catenin, c-myc and cyclin D1 in breast cancer cell lines, but not in normal breast cells [75, 76]. Different studies have also demonstrated the inactivation of negative regulators of the pathway, such as APC, axin, axin-2, secreted Frizzled related protein-1 (sFRP-1) [36, 77]. 
At transcriptional level, molecular markers such as APC, $\beta$-catenin, cyclin D1, c-Myc, COX2 and PPAR $\delta$ were selected. Semi quantitative reverse transcriptase PCR assay (Fig 5) revealed that M.Co could significantly downregulate mRNA levels of effector molecule $\beta$ catenin and downstream targets cyclin D1, c-myc, COX-2 and PPAR $\delta$ in both the cell lines. This supports the anti-proliferative and cell cycle arresting effect of M.Co. The cytoplasmic component APC, which is an essential part of $\beta$-catenin destruction complex and a negative regulator of the pathway, is found to be upregulated upon M.Co treatment in both cell lines.

Effect of M.Co on translational level expression of markers Wnt3A, Wnt5A, pLRP6 (active form of the receptor), pGSK3 $\beta$ (which indicates an active pathway), $\beta$ - catenin, cyclin D1 and E-cadherin was visualized using immunofluorescence staining and quantified by indirect ELISA. It is clear from the confocal microscopic images (Fig 6) that, the expression of autocrine Wnt ligand Wnt3A was suppressed and that of antagonistic ligand Wnt5A was upregulated by M.Co treatment in ER+ve and TNBC cell lines. Cell surface expression of Wnt co-receptor pLRP6 was very clear in both the control cells, which was found to be reduced in M.Co treated ones. Cytoplasmic expression of pGSK-3 $\beta$ was higher in control cells when compared to treated cells. Cytoplasmic and nuclear accumulation of $\beta$-catenin was clearly visible in MCF-7 and MDA-MB-231 control cells. M.Co treatment showed reduced $\beta$-catenin expression in MDA-MB-231 cells and complete inhibition of its nuclear translocation was visible in MCF-7 cells. M.Co induced downregulation of the downstream target cyclin-D1 in both the cell lines, which is supported by the G1/S transition arrest caused by M.Co. M.Co treatment induced upregulation of E-cadherin, which upon activation by Wnt 5A ligand forms a complex with $\beta$-catenin, making it unavailable for canonical Wnt pathway. Indirect ELISA results (Fig 7) also supported the observations made in immune staining. In both MCF-7 and MDA-MB-231 cell lines, M.Co treatment significantly downregulated the expression levels of autocrine ligand Wnt 3A, active receptor pLRP6, 
active cytoplasmic component pGSK-3 $\beta$, effector molecule $\beta$-catenin and downstream target cyclin D1. Meanwhile, the expression of canonical Wnt pathway antagonists Wnt5A and Ecadherin were significantly upregulated upon M.Co treatment, in both cell lines.

Many polyphenolic phytocompounds use regulation of irregular Wnt $/ \beta$-catenin signalling pathway as one of their anti-carcinogenic mechanisms. Some examples are: epigallocatechin3-gallate (EGCG) [78], quercetin [79], ellagic acid [80], genistein [81], curcumin [42], resveratrol [82], lycopene [83] and compound Kushen [84]. Polyphenol rich crude extracts such as total extract of white and green tea [45], Panax notoginseng extract [85], pomegranate extract [86], Ethanolic extracts of Angelica koreanae radix, Cannabis sativa semen, Ephedrae intermedia Schrenk radix, and Vitis rotundifolia fruit [46] and Antrodia camphorate [87] are also shown to regulate canonical Wnt signalling pathway. It is reported for the first time that the regulatory effect of $C$. oxyacantha berry extract on canonical Wnt signalling pathway is one of the mechanisms behind its anti-carcinogenic property on ER+ve (MCF-7) and triple negative (MDA-MB-231) breast cancer cell lines.

\section{Conclusion}

The methanolic extract of $C$. oxyacantha berry exhibits commendable in vitro anti-cancer effect against breast cancers, irrespective of their hormone dependency. The extract could effectively regulate canonical Wnt signalling pathway, at different stages, and it is found to be one of the mechanisms behind the cytotoxic, anti-proliferative and cell cycle arresting properties exhibited by the extract. Since canonical Wnt pathway regulation is involved, the extract can be looked forward to have anti-inflammatory and anti-metastatic properties. Canonical Wnt pathway regulation may enable the extract to inhibit cancer at stem cell level, which needs to be confirmed further. Hence, $C$. oxyacantha berry extract is a promising 
candidate to be developed as an effective drug against breast cancers, regardless of its receptor status.

\section{Declarations}

Funding: This work is funded by Department of Biotechnology (DBT), Government of India, in the form of Junior and Senior Research Fellowship.

Conflicts of interests: The authors have no conflicts of interest to declare that are relevant to the content of this article.

Availability of data and material: Yes. Data have been generated as part of the routine work.

Ethics approval: Not applicable

Consent for publication: The authors have their consent to publish their work

\section{Figure captions}

Fig 1: Study of Cytotoxic effect of M.Co on PBMCs, MCF-7 and MDA-MB-231 cell lines by MTT assay. All values are expressed as the mean \pm SD of three measurements

Fig 2: Morphological changes in control and M.Co treated MCF-7 and MDA-MB-231 cells. Phase contrast microscopic images (a) MCF-7 control cells (b) MCF-7 cells treated with M.Co for $24 \mathrm{~h}$ (c) MCF-7 cells treated with M.Co for $48 \mathrm{~h}$ (d) M.Co treated MCF-7 cells undergoing apoptosis (arrow) (e) MDA-MB-231 control cells (f) MDA-MB-231 cells treated with M.Co for $24 \mathrm{~h}$ (g) MDA-MB-231 cells treated with M.Co for $48 \mathrm{~h}$ (h) M.Co treated MDA-MB-231 cells undergoing apoptosis (arrow)

Fig 3: Study of anti-proliferative effect of M.Co on MCF-7 and MDA-MB-231 cell lines by clonogenic assay. Colonies stained with crystal violet (a) MCF-7 control cells (b) MCF-7 cells treated with M.Co for $24 \mathrm{~h}$ (c) MCF-7 cells treated with M.Co for $48 \mathrm{~h}$ (d) MDA-MB231 control cells (e) MDA-MB-231 cells treated with M.Co for $24 \mathrm{~h}$ and (f) MDA-MB-231 cells treated with M.Co for $48 \mathrm{~h}$

Fig 4: Study of effect of M.Co on cell cycle of MCF-7 and MDA-MB-231 cell lines by flow cytometry (PI staining). (a) control MCF-7 cells (b) MCF-7 cells treated with M.Co for $24 \mathrm{~h}$ (c) MCF-7 cells treated with M.Co for $48 \mathrm{~h}$ (d) graph depicting percentage of cells in each phase of cell cycle in control and M.Co treated MCF-7 cells (e) control MDA-MB-231 cells (f) MDA-MB-231 cells treated with M.Co for $24 \mathrm{~h}$ (g) MDA-MB-231 cells treated with M.Co for $48 \mathrm{~h}$ and (h) graph depicting percentage of cells in each phase of cell cycle in control and M.Co treated MDA-MB-231cells. Each value is expressed as mean \pm SD of three 
experiments. Statistical significance set at $\mathrm{p}<0.01$. Comparisons are made as a- control Vs M.Co (24h) and b- control vs M.Co (48h)

Fig 5: Study of the effect of M.Co on transcriptional level expression of APC, $\beta$ catenin, Cyclin D1, c-Myc, COX-2 and PPAR $\delta$ in control and M.Co treated MCF-7 and MDA-MB231 cells by Semi quantitative reverse transcriptase PCR. (a) RT-PCR products of APC, $\beta$ catenin, Cyclin D1, c-Myc, COX-2, PPAR $\delta$ and $\beta$ - actin (b \& c) Respective densitometry values normalized with $\beta$-actin and presented as "expression in arbitrary units"(using ImageJ software) of MCF-7 and MDA-MB-231 cell lines respectively. All values are expressed as the mean \pm SD of three measurements. Statistical significance set at $p<0.01$. Comparisons are made as $\mathrm{a}^{*}$ - control cells vs M.Co treated cells

Fig 6: Study of the effect of M.Co on translational level expression of Wnt 3A, Wnt 5A, pLRP6, pGSK3, $\beta$ catenin, Cyclin D1 and E-cadherin by immunofluorescence staining. (a) Control and M.Co treated MCF-7 cells (b) Control and M.Co treated MDA-MB-231 cells

Fig 7: Study of effect of M.Co on translational level expression of Wnt 3A, Wnt 5A, pLRP6, pGSK3, $\beta$ catenin, Cyclin D1 and E-cadherin by indirect ELISA. Values are represented as absorbance at $450 \mathrm{~nm}$. (a) Control and M.Co treated MCF-7 cells (b) Control and M.Co treated MDA-MB-231 cells. Each value is expressed as mean \pm SD of three experiments. Statistical significance set at $\mathrm{P}<0.01$. Comparisons are made as $\mathrm{a}^{*}$ - control cells vs M.Co treated cells

\section{References}

1. Perou, C. M., Sørlie, T., Eisen, M. B., van de Rijn, M., Jeffrey, S. S., Rees, C. A., Pollack, J. R., Ross, D. T., Johnsen, H., Akslen, L. A., Fluge, O., Pergamenschikov, A., Williams, C., Zhu, S. X., Lønning, P. E., Børresen-Dale, A. L., Brown, P. O., \& Botstein, D. (2000). Molecular portraits of human breast tumours. Nature, 406(6797), 747-752. https://doi.org/10.1038/35021093.

2. Powell, K. (2012). Molecular oncology: The positive in the negative. Nature, 485(7400), S52-S53. https://doi.org/10.1038/485S52a.

3. Dent, R., Trudeau, M., Pritchard, K. I., Hanna, W. M., Kahn, H. K., Sawka, C. A., Lickley, L. A., Rawlinson, E., Sun. P., \& Narod, S. A. (2007). Triple-negative breast cancer: clinical features and patterns of recurrence. Clinical cancer research: an official journal of the American Association for Cancer Research, 13(15 Pt 1), 44294434. https://doi.org/10.1158/1078-0432.CCR-06-3045.

4. Mense, S. M., Hei, T. K., Ganju, R. K., \& Bhat, H. K. (2008). Phytoestrogens and breast cancer prevention: possible mechanisms of action. Environmental health perspectives, 116(4), 426-433. https://doi.org/10.1289/ehp.10538.

5. Johnston, S. R. D. (2010). New Strategies in Estrogen Receptor-Positive Breast Cancer. Clinical Cancer Research, 16(7), 1979 LP - 1987. https://doi.org/10.1158/1078-0432.CCR-09-1823.

6. Hudis, C. A., \& Gianni, L. (2011). Triple-negative breast cancer: an unmet medical 
need. The oncologist, 16 Suppl 1, 1-11. https://doi.org/10.1634/theoncologist.2011S1-01.

7. Rastelli, F., Biancanelli, S., Falzetta, A., Martignetti, A., Casi, C., Bascioni, R., Giustini. L., \& Crispino, S. (2010). Triple-negative breast cancer: current state of the art. Tumori, 96(6), 875-888. https://doi.org/10.1700/548.6505.

8. Lyons, T. G. (2019). Targeted Therapies for Triple-Negative Breast Cancer. Current Treatment Options in Oncology, 20(11), 82. https://doi.org/10.1007/s11864-0190682-x.

9. Verma, S., Jain, V., Verma, D., \& Khamesra, A. (2007). Crataegus oxyacantha-A cardioprotective herb. journal of herbal medicine and toxicology, 1, 65-71.

10. Tassell, M. C., Kingston, R., Gilroy, D., Lehane, M., \& Furey, A. (2010). Hawthorn (Crataegus spp.) in the treatment of cardiovascular disease. Pharmacognosy reviews, 4(7), 32-41. https://doi.org/10.4103/0973-7847.65324.

11. Degenring, F. H., Suter, A., Weber, M., \& Saller, R. (2003). A randomised double blind placebo controlled clinical trial of a standardised extract of fresh Crataegus berries (Crataegisan) in the treatment of patients with congestive heart failure NYHA II. Phytomedicine: international journal of phytotherapy and phytopharmacology, 10(5), 363-369. https://doi.org/10.1078/0944-7113-00312.

12. Jayalakshmi, R., Thirupurasundari, C. J., \& Devaraj, S. N. (2006). Pretreatment with alcoholic extract of Crataegus oxycantha (AEC) activates mitochondrial protection during isoproterenol - induced myocardial infarction in rats. Molecular and cellular biochemistry, 292(1-2), 59-67. https://doi.org/10.1007/s11010-006-9218-3.

13. Swaminathan, J. K., Khan, M., Mohan, I. K., Selvendiran, K., Niranjali Devaraj, S., Rivera, B. K., \& Kuppusamy, P. (2010). Cardioprotective properties of Crataegus oxycantha extract against ischemia-reperfusion injury. Phytomedicine : international journal of phytotherapy and phytopharmacology, 17(10), 744-752. https://doi.org/10.1016/j.phymed.2010.01.009.

14. Chen, J. D., Wu, Y. Z., Tao, Z. L., Chen, Z. M., \& Liu, X. P. (1995). Hawthorn (Shan Zha) Drink and Its Lowering Effect on Blood Lipid Levels in Humans and Rats. In World Review of Nutrition and Dietetics (pp. 147-154). https://doi.org/10.1159/000424470.

15. Rajendran, S., Deepalakshmi, P. D., Parasakthy, K., Devaraj, H., \& Devaraj, S. N. (1996). Effect of tincture of Crataegus on the LDL-receptor activity of hepatic plasma membrane of rats fed an atherogenic diet. Atherosclerosis, 123(1), 235-241. https://doi.org/10.1016/0021-9150(96)05813-3.

16. Jouad, H., Lemhadri, A., Maghrani, M., Burcelin, R., \& Eddouks, M. (2003). Hawthorn evokes a potent anti-hyperglycemic capacity in streptozotocin-induced diabetic rats. Journal of herbal pharmacotherapy, 3(2), 19-29. https://doi.org/10.1300/J157v03n02_03.

17. Walker, A. F., Marakis, G., Simpson, E., Hope, J. L., Robinson, P. A., Hassanein, M., \& Simpson, H. C. R. (2006). Hypotensive effects of hawthorn for patients with diabetes taking prescription drugs: a randomised controlled trial. The British journal 
of general practice: the journal of the Royal College of General Practitioners, 56(527), 437-443.

18. Bahorun, T., Gressier, B., Trotin, F., Brunet, C., Dine, T., Luyckx, M., Vasseur, J., Cazin, M., Cazin, J. C.,\& Pinkas, M. (1996). Oxygen species scavenging activity of phenolic extracts from hawthorn fresh plant organs and pharmaceutical preparations. Arzneimittel-Forschung, 46(11), 1086-1089.

19. Zhang, Z., Chang, Q., Zhu, M., Huang, Y., Ho, W. K. K., \& Chen, Z.-Y. (2001). Characterization of antioxidants present in hawthorn fruits. The Journal of nutritional biochemistry, 12(3), 144-152. https://doi.org/10.1016/s0955-2863(00)00137-6.

20. Kao, E.-S., Wang, C.-J., Lin, W.-L., Yin, Y.-F., Wang, C.-P., \& Tseng, T.-H. (2005). Anti-inflammatory potential of flavonoid contents from dried fruit of Crataegus pinnatifida in vitro and in vivo. Journal of agricultural and food chemistry, 53(2), 430-436. https://doi.org/10.1021/jf040231f.

21. Tadić, V. M., Dobrić, S., Marković, G. M., Dordević, S. M., Arsić, I. A., Menković, N. R., \& Stević, T. (2008). Anti-inflammatory, gastroprotective, free-radicalscavenging, and antimicrobial activities of hawthorn berries ethanol extract. Journal of agricultural and food chemistry, 56(17), 7700-7709. https://doi.org/10.1021/jf801668c.

22. Li, C., \& Wang, M.-H. (2011). Anti-inflammatory effect of the water fraction from hawthorn fruit on LPS-stimulated RAW 264.7 cells. Nutrition research and practice, 5(2), 101-106. https://doi.org/10.4162/nrp.2011.5.2.101.

23. Sáenz, M. T., Ahumada, M. C., \& García, M. D. (1997). Extracts from Viscum and Crataegus are cytotoxic against larynx cancer cells. Zeitschrift fur Naturforschung. $C$, Journal of biosciences, 52(1-2), 42-44.

24. Satoh, K., Anzai, S., \& Sakagami, H. (1998). Enhancement of radical intensity and cytotoxic activity of ascorbate by Crataegus cuneata Sieb et. Zucc. extracts. Anticancer research, 18(4A), 2749-2753.

25. Min, B. S., Kim, Y. H., Lee, S. M., Jung, H. J., Lee, J. S., Na, M. K., Lee, C. O., Lee, J. P., \& Bae, K. (2000). Cytotoxic triterpenes from Crataegus pinnatifida. Archives of pharmacal research, 23(2), 155-158. https://doi.org/10.1007/BF02975505.

26. Elango, C., \& Devaraj, S. N. (2010). Immunomodulatory effect of Hawthorn extract in an experimental stroke model. Journal of neuroinflammation, 7, 97. https://doi.org/10.1186/1742-2094-7-97.

27. Thirupurasundari, C. J., Jayalakshmi, R., \& Niranjali Devaraj, S. (2005). Liver architecture maintenance by tincture of Crataegus against isoproterenol-induced myocardially infarcted rats. Journal of medicinal food, 8(3), 400-404. https://doi.org/10.1089/jmf.2005.8.400.

28. Kao, E.-S., Wang, C.-J., Lin, W.-L., Chu, C.-Y., \& Tseng, T.-H. (2007). Effects of polyphenols derived from fruit of Crataegus pinnatifida on cell transformation, dermal edema and skin tumor formation by phorbol ester application. Food and chemical toxicology: an international journal published for the British Industrial Biological Research Association, 45(10), 1795-1804. 
https://doi.org/10.1016/j.fct.2007.03.016.

29. Cui, T., Li, J.-Z., Kayahara, H., Ma, L., Wu, L.-X., \& Nakamura, K. (2006). Quantification of the polyphenols and triterpene acids in chinese hawthorn fruit by high-performance liquid chromatography. Journal of agricultural and food chemistry, 54(13), 4574-4581. https://doi.org/10.1021/jf060310m.

30. Svedström, U., Vuorela, H., Kostiainen, R., Laakso, I., \& Hiltunen, R. (2006). Fractionation of polyphenols in hawthorn into polymeric procyanidins, phenolic acids and flavonoids prior to high-performance liquid chromatographic analysis. Journal of chromatography. A, 1112(1-2), 103-111. https://doi.org/10.1016/j.chroma.2005.12.080.

31. Davies, J. R. (2000). Hawthorn: Crataegus Monogyna (In a Nutshell) (In a Nutshell S.: Healing Herbs). Element. Retrieved from https://www.amazon.in/HawthornCrataegus-Monogyna-Nutshell-Healing/dp/1862045577.

32. Moon, R. T., Kohn, A. D., De Ferrari, G. V, \& Kaykas, A. (2004). WNT and betacatenin signalling: diseases and therapies. Nature reviews. Genetics, 5(9), 691-701. https://doi.org/10.1038/nrg1427.

33. Katoh, M. (2017). Canonical and non-canonical WNT signaling in cancer stem cells and their niches: Cellular heterogeneity, omics reprogramming, targeted therapy and tumor plasticity (Review). International journal of oncology, 51(5), 1357-1369. https://doi.org/10.3892/ijo.2017.4129.

34. Chu, E. Y., Hens, J., Andl, T., Kairo, A., Yamaguchi, T. P., Brisken, C., Glick, A., Wysolmerski, J. J., \& Millar, S. E. (2004). Canonical WNT signaling promotes mammary placode development and is essential for initiation of mammary gland morphogenesis. Development (Cambridge, England), 131(19), 4819-4829. https://doi.org/10.1242/dev.01347.

35. Roelink, H., Wagenaar, E., Lopes da Silva, S., \& Nusse, R. (1990). Wnt-3, a gene activated by proviral insertion in mouse mammary tumors, is homologous to int1/Wnt-1 and is normally expressed in mouse embryos and adult brain. Proceedings of the National Academy of Sciences of the United States of America, 87(12), 45194523. https://doi.org/10.1073/pnas.87.12.4519.

36. Ugolini, F., Charafe-Jauffret, E., Bardou, V. J., Geneix, J., Adélaïde, J., LabatMoleur, F., Penault-Llorca, F., Longy, M., Jacquemier, J., Birnbaum, D., \& Pébusque, M. J. (2001). WNT pathway and mammary carcinogenesis: loss of expression of candidate tumor suppressor gene SFRP1 in most invasive carcinomas except of the medullary type. $\quad$ Oncogene, 20(41), 5810-5817. https://doi.org/10.1038/sj.onc.1204706.

37. Smalley, M. J., \& Dale, T. C. (2001). Wnt signaling and mammary tumorigenesis. Journal of mammary gland biology and neoplasia, 6(1), 37-52. https://doi.org/10.1023/a:1009564431268.

38. Saitoh, T., Mine, T., \& Katoh, M. (2002). Up-regulation of Frizzled-10 (FZD10) by $\beta$-estradiol in MCF-7 cells and by retinoic acid in NT2 cells. International Journal of Oncology, 20(1), 117-120. https://doi.org/10.3892/ijo.20.1.117. 
39. Matsuda, Y., Schlange, T., Oakeley, E. J., Boulay, A., \& Hynes, N. E. (2009). WNT signaling enhances breast cancer cell motility and blockade of the WNT pathway by sFRP1 suppresses MDA-MB-231 xenograft growth. Breast cancer research: BCR, 11(3), R32. https://doi.org/10.1186/bcr2317.

40. Benhaj, K., Akcali, K. C., \& Ozturk, M. (2006). Redundant expression of canonical Wnt ligands in human breast cancer cell lines. Oncology reports, 15(3), 701-707.

41. Kim, J., Zhang, X., Rieger-Christ, K. M., Summerhayes, I. C., Wazer, D. E., Paulson, K. E., \& Yee, A. S. (2006). Suppression of Wnt signaling by the green tea compound (-)-epigallocatechin 3-gallate (EGCG) in invasive breast cancer cells. Requirement of the transcriptional repressor HBP1. The Journal of biological chemistry, 281(16), 10865-10875. https://doi.org/10.1074/jbc.M513378200.

42. Ryu, M.-J., Cho, M., Song, J.-Y., Yun, Y.-S., Choi, I.-W., Kim, D.-E., Park, B.-S., \& Oh, S. (2008). Natural derivatives of curcumin attenuate the Wnt/beta-catenin pathway through down-regulation of the transcriptional coactivator p300. Biochemical and biophysical research communications, 377(4), 1304-1308. https://doi.org/10.1016/j.bbrc.2008.10.171.

43. Park, S., \& Choi, J. (2010). Inhibition of beta-catenin/Tcf signaling by flavonoids. Journal of cellular biochemistry, 110(6), 1376-1385. https://doi.org/10.1002/jcb.22654.

44. Tarapore, R. S., Siddiqui, I. A., \& Mukhtar, H. (2012). Modulation of Wnt/ $\beta$-catenin signaling pathway by bioactive food components. Carcinogenesis, 33(3), 483-491. https://doi.org/10.1093/carcin/bgr305.

45. Dashwood, W.-M., Orner, G. A., \& Dashwood, R. H. (2002). Inhibition of betacatenin/Tcf activity by white tea, green tea, and epigallocatechin-3-gallate (EGCG): minor contribution of $\mathrm{H}(2) \mathrm{O}(2)$ at physiologically relevant EGCG concentrations. Biochemical and biophysical research communications, 296(3), 584-588. https://doi.org/10.1016/s0006-291x(02)00914-2.

46. Choe, Y., Na, B., \& Park, S. (2011). Screening of $\beta$-Catenin / TCF Transcription Factor Inhibitors in Medicinal Herb Extracts. The Journal of Korean Oriental Medicine, 32(3), 35-43.

47. Kanof, M. E., Smith, P. D., \& Zola, H. (2001). Isolation of whole mononuclear cells from peripheral blood and cord blood. Current protocols in immunology, Chapter 7, Unit 7.1. https://doi.org/10.1002/0471142735.im0701s19.

48. Mosmann, T. (1983). Rapid colorimetric assay for cellular growth and survival: application to proliferation and cytotoxicity assays. Journal of immunological methods, 65(1-2), 55-63. https://doi.org/10.1016/0022-1759(83)90303-4.

49. Hagedorn, C., Baiker, A., Postberg, J., Ehrhardt, A., \& Lipps, H. J. (2012). A colonyforming assay for determining the establishment efficiency of S/MAR-containing nonviral episomal expression vectors. Cold Spring Harbor protocols, 2012(6), 706708. https://doi.org/10.1101/pdb.prot069500.

50. Hsu, Y.-L., Kuo, P.-L., Lin, L.-T., \& Lin, C.-C. (2005). Asiatic acid, a triterpene, induces apoptosis and cell cycle arrest through activation of extracellular signal- 
regulated kinase and p38 mitogen-activated protein kinase pathways in human breast cancer cells. The Journal of pharmacology and experimental therapeutics, 313(1), 333-344. https://doi.org/10.1124/jpet.104.078808.

51. Chomczynski, P., \& Sacchi, N. (1987). Single-step method of RNA isolation by acid guanidinium thiocyanate-phenol-chloroform extraction. Analytical biochemistry, 162(1), 156-159. https://doi.org/10.1006/abio.1987.9999.

52. Kawasaki, E. (1990). Amplification of RNA. In T. Innis, MA; Gefland, DH; Sninsky, $\mathrm{JJ}$ and White (Ed.), PCR Protocols, a guide to methods and applications (pp. 21-27).

53. Marone, M., Mozzetti, S., De Ritis, D., Pierelli, L., \& Scambia, G. (2001). Semiquantitative RT-PCR analysis to assess the expression levels of multiple transcripts from the same sample. Biological procedures online, 3, 19-25. https://doi.org/10.1251/bpo20.

54. Donaldson, J. G. (2001). Immunofluorescence staining. Current protocols in cell biology, Chapter 4, Unit-4.3. https://doi.org/10.1002/0471143030.cb0403s00.

55. Lowry, O. H., Rosebrough, N. J., Farr, A. L., \& Randall, R. J. (1951). Protein measurement with the Folin phenol reagent. The Journal of biological chemistry, 193(1), 265-275.

56. Le, T., Yu, H., Guo, Y., Ngom, B., Shen, Y., \& Bi, D. (2009). Development of an indirect competitive ELISA for the detection of doxycycline residue in animal edible tissues. Food and Agricultural Immunology, 20(2), 111-124. https://doi.org/10.1080/09540100902849740.

57. Duthie, S. J. (2007). Berry phytochemicals, genomic stability and cancer: evidence for chemoprotection at several stages in the carcinogenic process. Molecular nutrition \& food research, 51(6), 665-674. https://doi.org/10.1002/mnfr.200600257.

58. Seeram, N. P. (2008). Berry Fruits for Cancer Prevention: Current Status and Future Prospects. Journal of Agricultural and Food Chemistry, 56(3), 630-635. https://doi.org/10.1021/jf072504n.

59. Vierling, W., Brand, N., Gaedcke, F., Sensch, K. H., Schneider, E., \& Scholz, M. (2003). Investigation of the pharmaceutical and pharmacological equivalence of different Hawthorn extracts. Phytomedicine: international journal of phytotherapy and phytopharmacology, 10(1), 8-16. https://doi.org/10.1078/094471103321648601.

60. Becker, H. (2001). Anticancer Activity Found in Berry Extracts. Agri Res, 49(5), 22. Retrieved from https://www.proquest.com/scholarly-journals/anticancer-activityfound-berry-extracts/docview/208041542/se-2? accountid=201395.

61. Kaur, M., Agarwal, C., \& Agarwal, R. (2009). Anticancer and cancer chemopreventive potential of grape seed extract and other grape-based products. The Journal of nutrition, 139(9), 1806S-12S. https://doi.org/10.3945/jn.109.106864.

62. Rao, Y. K., Geethangili, M., Fang, S.-H., \& Tzeng, Y.-M. (2007). Antioxidant and cytotoxic activities of naturally occurring phenolic and related compounds: a comparative study. Food and chemical toxicology : an international journal published for the British Industrial Biological Research Association, 45(9), 1770-1776. 
https://doi.org/10.1016/j.fct.2007.03.012.

63. Frisch, S. M., \& Francis, H. (1994). Disruption of epithelial cell-matrix interactions induces apoptosis. The Journal of cell biology, 124(4), 619-626. https://doi.org/10.1083/jcb.124.4.619.

64. Franken, N. A. P., Rodermond, H. M., Stap, J., Haveman, J., \& van Bree, C. (2006). Clonogenic assay of cells in vitro. Nature protocols, 1(5), 2315-2319. https://doi.org/10.1038/nprot.2006.339.

65. Hoffman, R. M. (1991). In vitro sensitivity assays in cancer: a review, analysis, and prognosis. Journal of clinical laboratory analysis, 5(2), 133-143. https://doi.org/10.1002/jcla.1860050211.

66. Johansson, M., \& Persson, J. L. (2008). Cancer therapy: targeting cell cycle regulators. Anti-cancer agents in medicinal chemistry, 8(7), 723-731. https://doi.org/10.2174/187152008785914833.

67. Jordan, M. A., Thrower, D., \& Wilson, L. (1991). Mechanism of inhibition of cell proliferation by Vinca alkaloids. Cancer research, 51(8), 2212-2222.

68. Hogan, F. S., Krishnegowda, N. K., Mikhailova, M., \& Kahlenberg, M. S. (2007). Flavonoid, silibinin, inhibits proliferation and promotes cell-cycle arrest of human colon cancer. The Journal of surgical research, 143(1), 58-65. https://doi.org/10.1016/j.jss.2007.03.080.

69. Pozo-Guisado, E., Alvarez-Barrientos, A., Mulero-Navarro, S., Santiago-Josefat, B., \& Fernandez-Salguero, P. M. (2002). The antiproliferative activity of resveratrol results in apoptosis in MCF-7 but not in MDA-MB-231 human breast cancer cells: cell-specific alteration of the cell cycle. Biochemical pharmacology, 64(9), 13751386. https://doi.org/10.1016/s0006-2952(02)01296-0.

70. Schlange, T., Matsuda, Y., Lienhard, S., Huber, A., \& Hynes, N. E. (2007). Autocrine WNT signaling contributes to breast cancer cell proliferation via the canonical WNT pathway and EGFR transactivation. Breast cancer research: $B C R, 9(5), \mathrm{R} 63$. https://doi.org/10.1186/bcr1769.

71. Geyer, F. C., Lacroix-Triki, M., Savage, K., Arnedos, M., Lambros, M. B., MacKay, A., Natrajan, R., \& Reis-Filho, J. S. (2011). $\beta$-Catenin pathway activation in breast cancer is associated with triple-negative phenotype but not with CTNNB1 mutation. Modern pathology : an official journal of the United States and Canadian Academy of Pathology, Inc, 24(2), 209-231. https://doi.org/10.1038/modpathol.2010.205.

72. Eisenmann, D. (2005). Wnt signaling. In The worm Book. The C. elegans Research Community. Retrieved from http://www.wormbook.org/chapters/www_wntsignaling.2/wntsignal.html.

73. Medrek, C., Landberg, G., Andersson, T., \& Leandersson, K. (2009). Wnt-5a-CKI $\alpha$ signaling promotes $\beta$-catenin/E-cadherin complex formation and intercellular adhesion in human breast epithelial cells. The Journal of biological chemistry, 284(16), 10968-10979. https://doi.org/10.1074/jbc.M804923200.

74. Ishitani, T., Kishida, S., Hyodo-Miura, J., Ueno, N., Yasuda, J., Waterman, M., 
Shibuya, H., Moon, R. T., Ninomiya-Tsuji, J., \& Matsumoto, K. (2003). The TAK1NLK mitogen-activated protein kinase cascade functions in the Wnt-5a/Ca(2+) pathway to antagonize Wnt/beta-catenin signaling. Molecular and cellular biology, 23(1), 131-139. https://doi.org/10.1128/MCB.23.1.131-139.2003.

75. Michaelson, J. S., \& Leder, P. (2001). beta-catenin is a downstream effector of Wntmediated tumorigenesis in the mammary gland. Oncogene, 20(37), 5093-5099. https://doi.org/10.1038/sj.onc.1204586.

76. Khramtsov, A. I., Khramtsova, G. F., Tretiakova, M., Huo, D., Olopade, O. I., \& Goss, K. H. (2010). Wnt/beta-catenin pathway activation is enriched in basal-like breast cancers and predicts poor outcome. The American journal of pathology, 176(6), 2911-2920. https://doi.org/10.2353/ajpath.2010.091125.

77. Howe, L. R., \& Brown, A. M. C. (2004). Wnt signaling and breast cancer. Cancer biology \& therapy, 3(1), 36-41. https://doi.org/10.4161/cbt.3.1.561.

78. Pahlke, G., Ngiewih, Y., Kern, M., Jakobs, S., Marko, D., \& Eisenbrand, G. (2006). Impact of quercetin and EGCG on key elements of the Wnt pathway in human colon carcinoma cells. Journal of agricultural and food chemistry, 54(19), 7075-7082. https://doi.org/10.1021/jf0612530.

79. Park, C. H., Chang, J. Y., Hahm, E. R., Park, S., Kim, H.-K., \& Yang, C. H. (2005). Quercetin, a potent inhibitor against beta-catenin/Tcf signaling in SW480 colon cancer cells. Biochemical and biophysical research communications, 328(1), 227234. https://doi.org/10.1016/j.bbrc.2004.12.151.

80. Cozza, G., Bonvini, P., Zorzi, E., Poletto, G., Pagano, M. A., Sarno, S., DonellaDeana, A., Zagotto, G., Rosolen, A., Pinna, L. A., Meggio, F., \& Moro, S. (2006). Identification of ellagic acid as potent inhibitor of protein kinase CK2: a successful example of a virtual screening application. Journal of medicinal chemistry, 49(8), 2363-2366. https://doi.org/10.1021/jm060112m.

81. Su, Y., \& Simmen, R. C. M. (2009). Soy isoflavone genistein upregulates epithelial adhesion molecule E-cadherin expression and attenuates beta-catenin signaling in mammary epithelial cells. Carcinogenesis, 30(2), 331-339. https://doi.org/10.1093/carcin/bgn279.

82. Hope, C., Planutis, K., Planutiene, M., Moyer, M. P., Johal, K. S., Woo, J., Santoso, C., Hanson, J. A., \& Holcombe, R. F. (2008). Low concentrations of resveratrol inhibit Wnt signal throughput in colon-derived cells: implications for colon cancer prevention. Molecular nutrition \& food research, 52 Suppl 1(Suppl 1), S52-61. https://doi.org/10.1002/mnfr.200700448.

83. Sarkar, F. H., Li, Y., Wang, Z., \& Kong, D. (2010). The role of nutraceuticals in the regulation of Wnt and Hedgehog signaling in cancer. Cancer metastasis reviews, 29(3), 383-394. https://doi.org/10.1007/s10555-010-9233-4.

84. Xu, W., Lin, H., Zhang, Y., Chen, X., Hua, B., Hou, W., Qi, X., Pei, Y., Zhu, X., Zhao, Z., \& Yang, L. (2011). Compound Kushen Injection suppresses human breast cancer stem-like cells by down-regulating the canonical Wnt/ $\beta$-catenin pathway. Journal of experimental \& clinical cancer research: $C R, 30(1), 103$. https://doi.org/10.1186/1756-9966-30-103. 
85. Bi, X., Zhao, Y., Fang, W., \& Yang, W. (2009). Anticancer activity of Panax notoginseng extract 20(S)-25-OCH3-PPD: Targetting beta-catenin signalling. Clinical and experimental pharmacology \& physiology, 36(11), 1074-1078. https://doi.org/10.1111/j.1440-1681.2009.05203.x.

86. Dai, Z., Nair, V., Khan, M., \& Ciolino, H. P. (2010). Pomegranate extract inhibits the proliferation and viability of MMTV-Wnt-1 mouse mammary cancer stem cells in vitro. Oncology reports, 24(4), 1087-1091.

87. Hseu, Y.-C., Tsou, H.-T., Kumar, K. J. S., Lin, K.-Y., Chang, H.-W., \& Yang, H.-L. (2012). The Antitumor Activity of Antrodia camphorata in Melanoma Cells: Modulation of Wnt/ $\beta$-Catenin Signaling Pathways. Evidence-based complementary and alternative medicine: eCAM, 2012, 197309. https://doi.org/10.1155/2012/197309. 
Figures

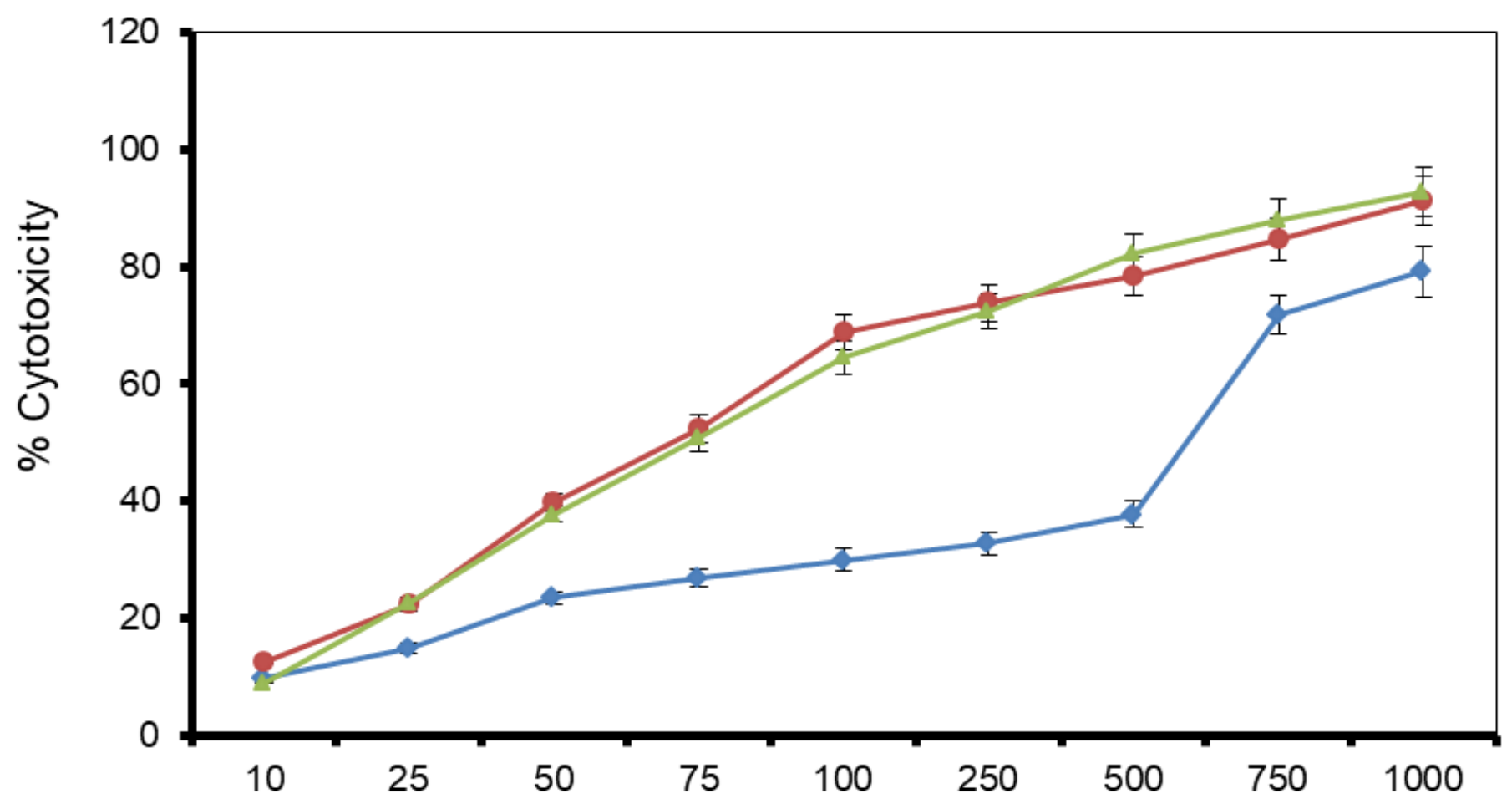

Concentration $(\mu \mathrm{g} / \mathrm{ml})$

$\multimap$ PBMC $\longrightarrow$ MCF-7 $\quad \longrightarrow$ MDA-MB-231

Figure 1

Study of Cytotoxic effect of M.Co on PBMCs, MCF-7 and MDA-MB-231 cell lines by MTT assay. All values are expressed as the mean \pm SD of three measurements 


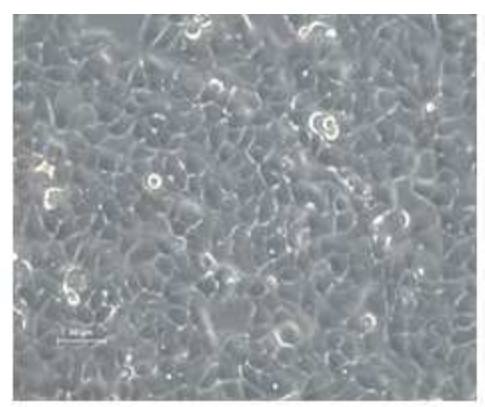

a. MCF-7 control

$(10 \mathrm{X})$

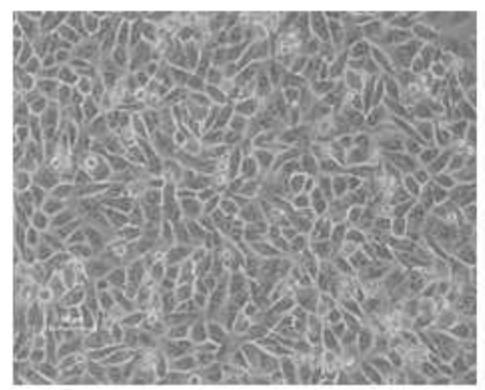

e. MDA-MB-231 control

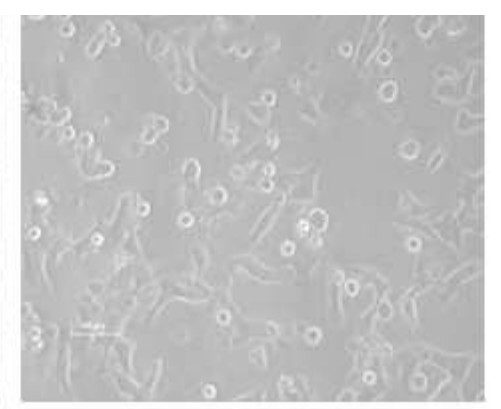

b. $\mathrm{MCF}-7+\mathrm{M} . \mathrm{Co}(24 \mathrm{~h})$

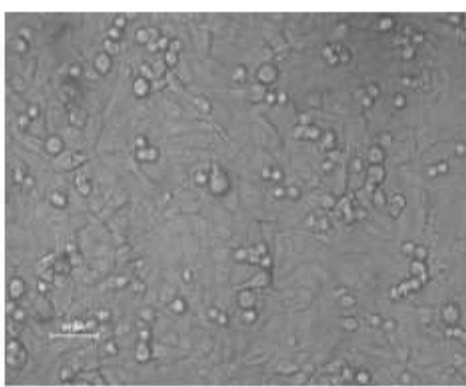

f. MDA-MB-231 + M.Co (24h)

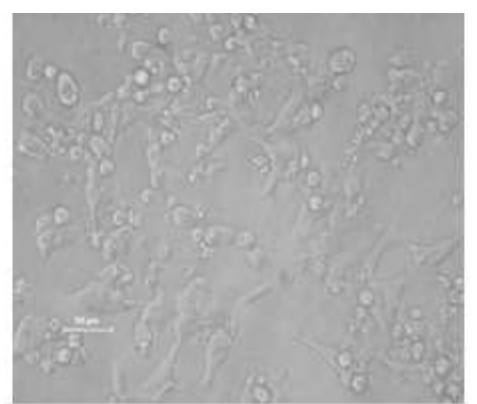

c. $\mathrm{MCF}-7+\mathrm{M} . \mathrm{Co}(48 \mathrm{~h})$

$(10 \mathrm{X})$

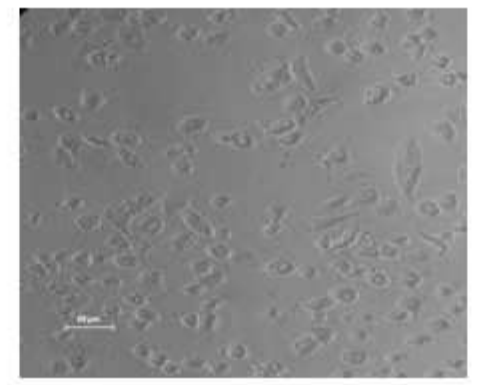

g. MDA-MB-231 + M.Co (48h)

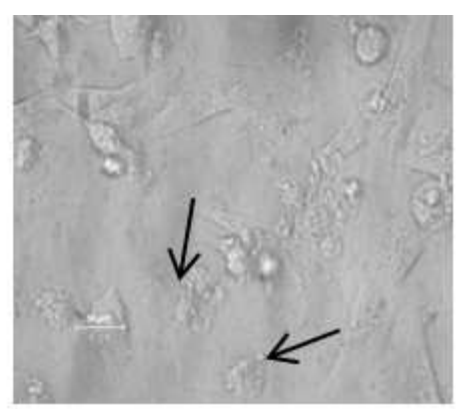

d. $\mathrm{MCF}-7+\mathrm{M} . \mathrm{Co}(48 \mathrm{~h})$

$(25 \mathrm{X})$

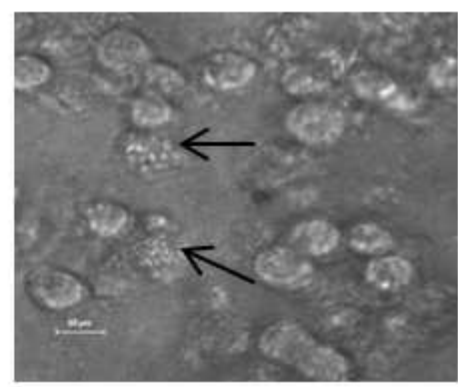

h. MDA-MB-231 + M.Co (48h) $(40 \mathrm{X})$

\section{Figure 2}

Morphological changes in control and M.Co treated MCF-7 and MDA-MB-231 cells. Phase contrast microscopic images (a) MCF-7 control cells (b) MCF-7 cells treated with M.Co for $24 \mathrm{~h}$ (c) MCF-7 cells treated with M.Co for $48 \mathrm{~h}$ (d) M.Co treated MCF-7 cells undergoing apoptosis (arrow) (e) MDA-MB-231 control cells (f) MDA-MB-231 cells treated with M.Co for $24 \mathrm{~h}(\mathrm{~g})$ MDA-MB-231 cells treated with M.Co for $48 \mathrm{~h}(\mathrm{~h})$ M.Co treated MDA-MB-231 cells undergoing apoptosis (arrow) 


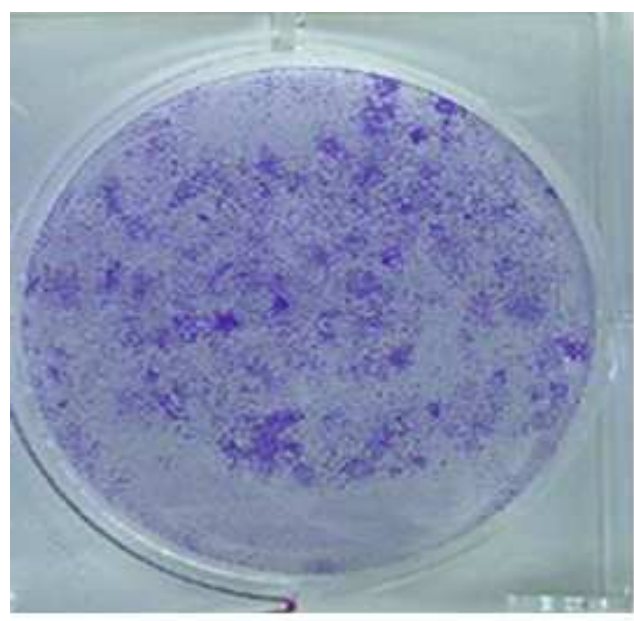

a. MCF-7 Control

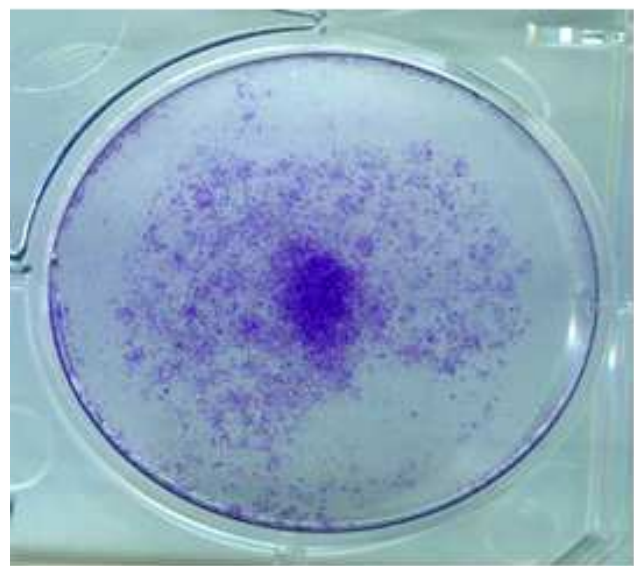

d. MDA-MB-231 Control

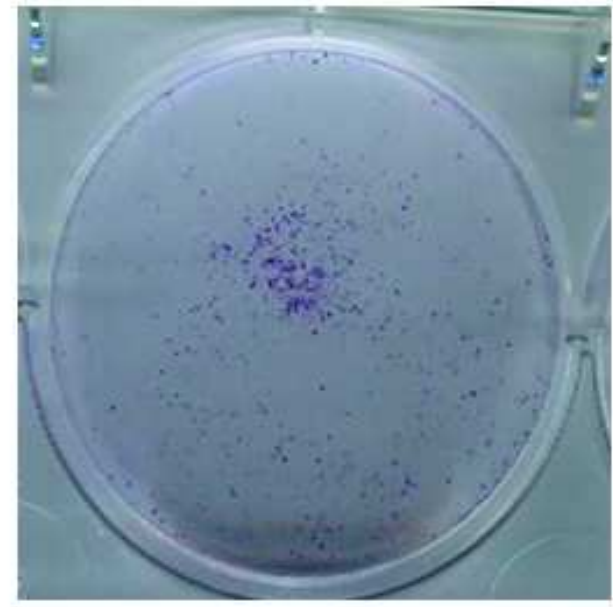

b. $\mathrm{MCF}-7+\mathrm{M} . \mathrm{Co}(24 \mathrm{~h})$

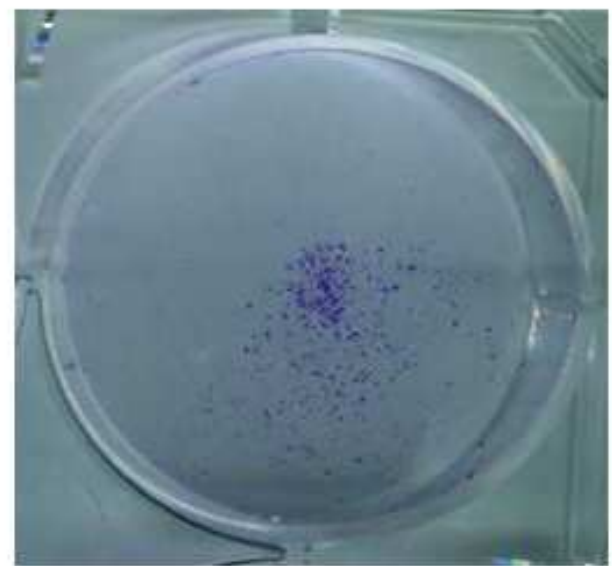

e. MDA-MB-231+M.Co(24h)

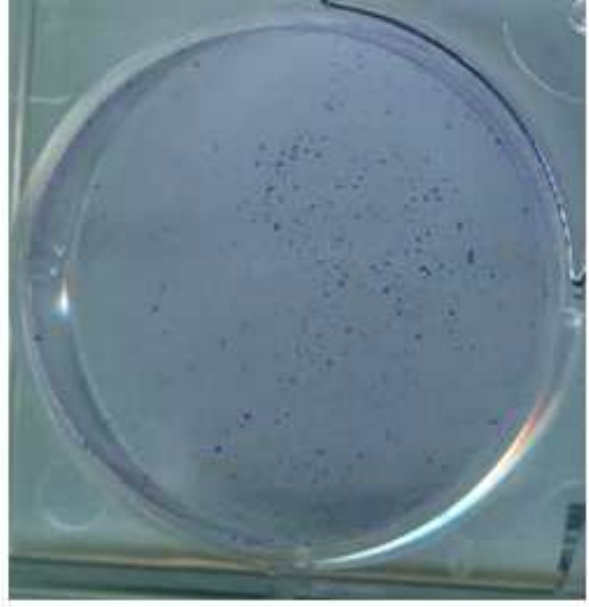

c. $\mathrm{MCF}-7+\mathrm{M} \cdot \mathrm{Co}(48 \mathrm{~h})$

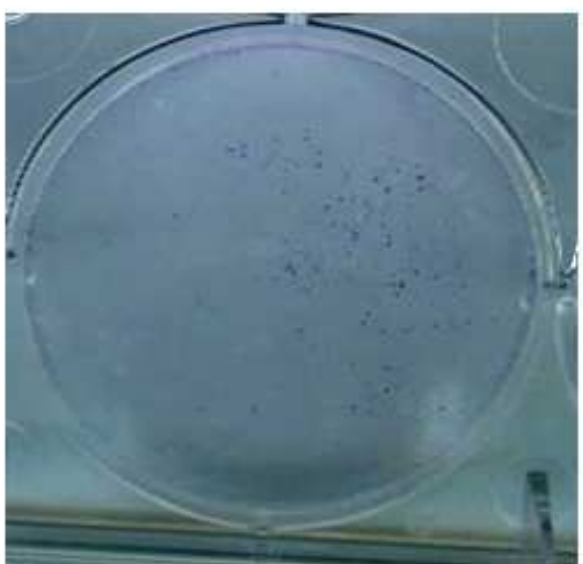

f. MDA-MB-231+M.Co (48h)

\section{Figure 3}

Study of anti-proliferative effect of M.Co on MCF-7 and MDA-MB-231 cell lines by clonogenic assay. Colonies stained with crystal violet (a) MCF-7 control cells (b) MCF-7 cells treated with M.Co for $24 \mathrm{~h}$ (c) MCF-7 cells treated with M.Co for $48 \mathrm{~h}$ (d) MDA-MB-231 control cells (e) MDA-MB-231 cells treated with M.Co for $24 \mathrm{~h}$ and (f) MDA-MB-231 cells treated with M.Co for $48 \mathrm{~h}$ 


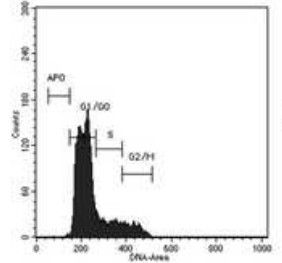

a. MCF-7 control

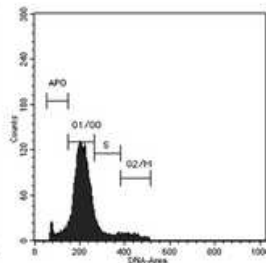

b. MCF $-7+$ M.Co $(24$ h $)$

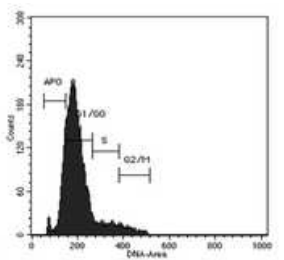

c. MCF $-7+\mathrm{M} \cdot \mathrm{Co}(48 \mathrm{~h})$

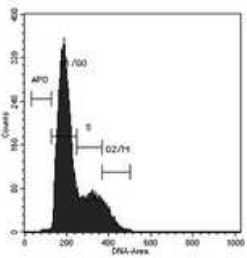

e. MDA-MB-231 control

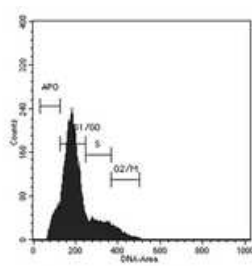

f. MDA-MB-231+ M.Co $(24 \mathrm{~h})$

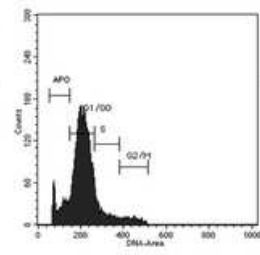

g. MDA-MB-231+ M.Co (48h) d

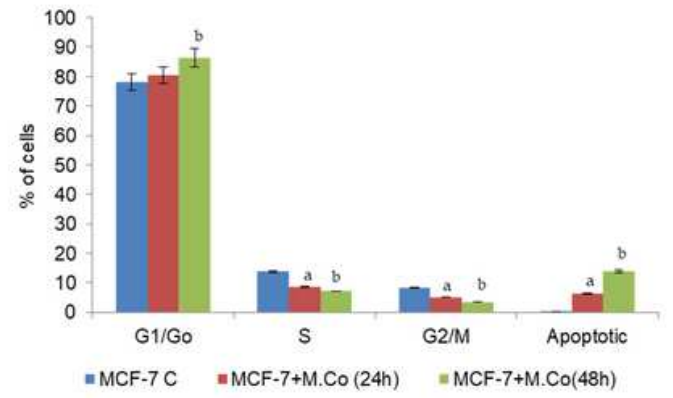

h

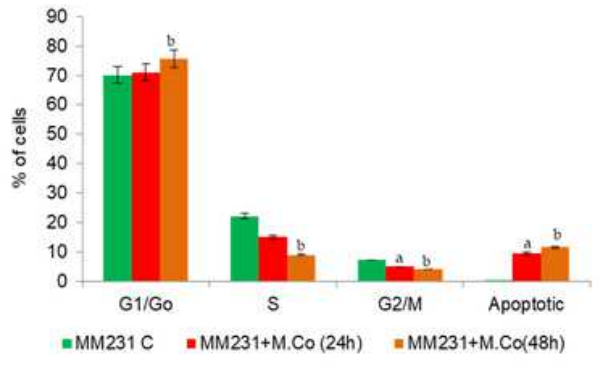

\section{Figure 4}

Study of effect of M.Co on cell cycle of MCF-7 and MDA-MB-231 cell lines by flow cytometry (PI staining). (a) control MCF-7 cells (b) MCF-7 cells treated with M.Co for $24 \mathrm{~h}$ (c) MCF-7 cells treated with M.Co for 48 $h$ (d) graph depicting percentage of cells in each phase of cell cycle in control and M.Co treated MCF-7 cells (e) control MDA-MB-231 cells (f) MDA-MB-231 cells treated with M.Co for $24 \mathrm{~h}$ (g) MDA-MB-231 cells treated with M.Co for $48 \mathrm{~h}$ and $(\mathrm{h})$ graph depicting percentage of cells in each phase of cell cycle in control and M.Co treated MDA-MB-231 cells. Each value is expressed as mean \pm SD of three experiments. Statistical significance set at $p<0.01$. Comparisons are made as a- control Vs M.Co (24h) and b-control vs M.Co (48h) 

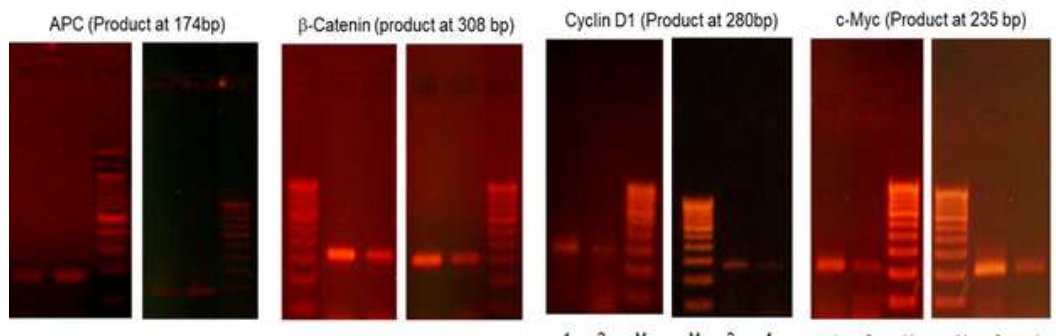

COX.2 (Product at 306 bp)

PPAR $\delta$ (Product at $165 \mathrm{bp}$ )

$\beta$ - actin (Product at $250 \mathrm{bp}$ )
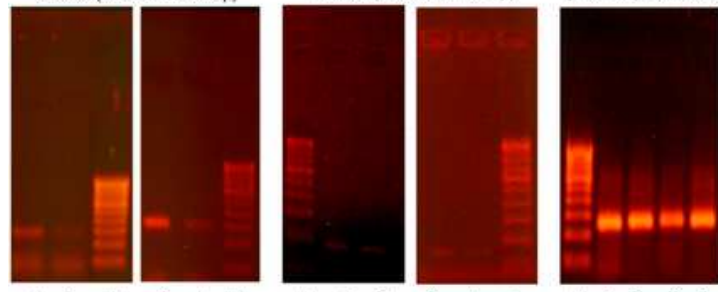

M- 100bp marke

1. MCF-7 control

2-MCF-7 treated with M.Co

3-MDA-MB-231 control

4- MDA-MB-231 treated with M.Co

$12 \mathrm{M} 34 \mathrm{M}$

$\begin{array}{llllll}M & 1 & 2 & 3 & 4 & M\end{array}$

$\begin{array}{lllll}M & 1 & 2 & 3 & 5\end{array}$

b

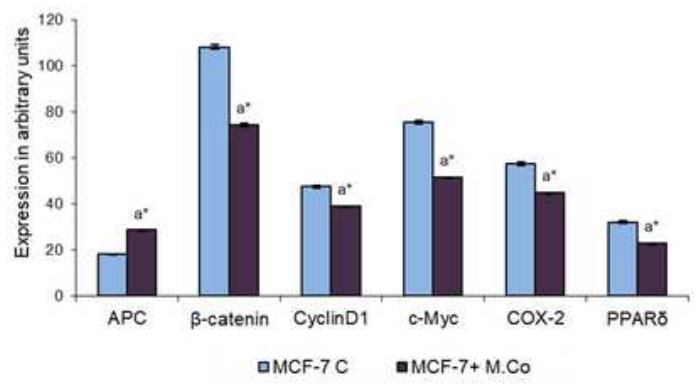

c

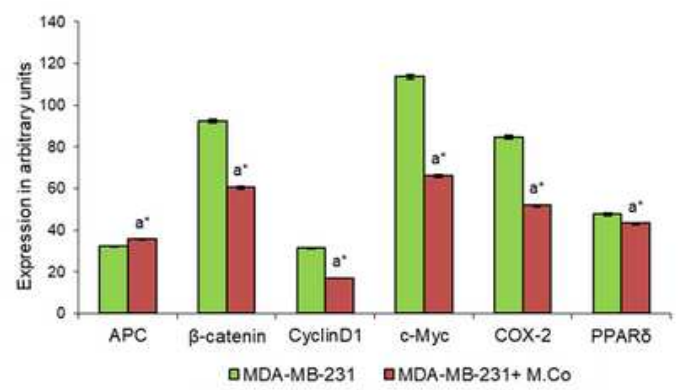

Figure 5

Study of the effect of M.Co on transcriptional level expression of APC, $\beta$ catenin, Cyclin D1, c-Myc, COX-2 and PPAR in control and M.Co treated MCF-7 and MDA-MB-231 cells by Semi quantitative reverse transcriptase PCR. (a) RT-PCR products of APC, $\beta$ catenin, Cyclin D1, c-Myc, COX-2, PPAR $\delta$ and $\beta$ - actin (b $\& \mathrm{c})$ Respective densitometry values normalized with $\beta$-actin and presented as "expression in arbitrary units"(using ImageJ software) of MCF-7 and MDA-MB-231 cell lines respectively. All values are expressed 
as the mean \pm SD of three measurements. Statistical significance set at $p<0.01$. Comparisons are made as a*- control cells vs M.Co treated cells

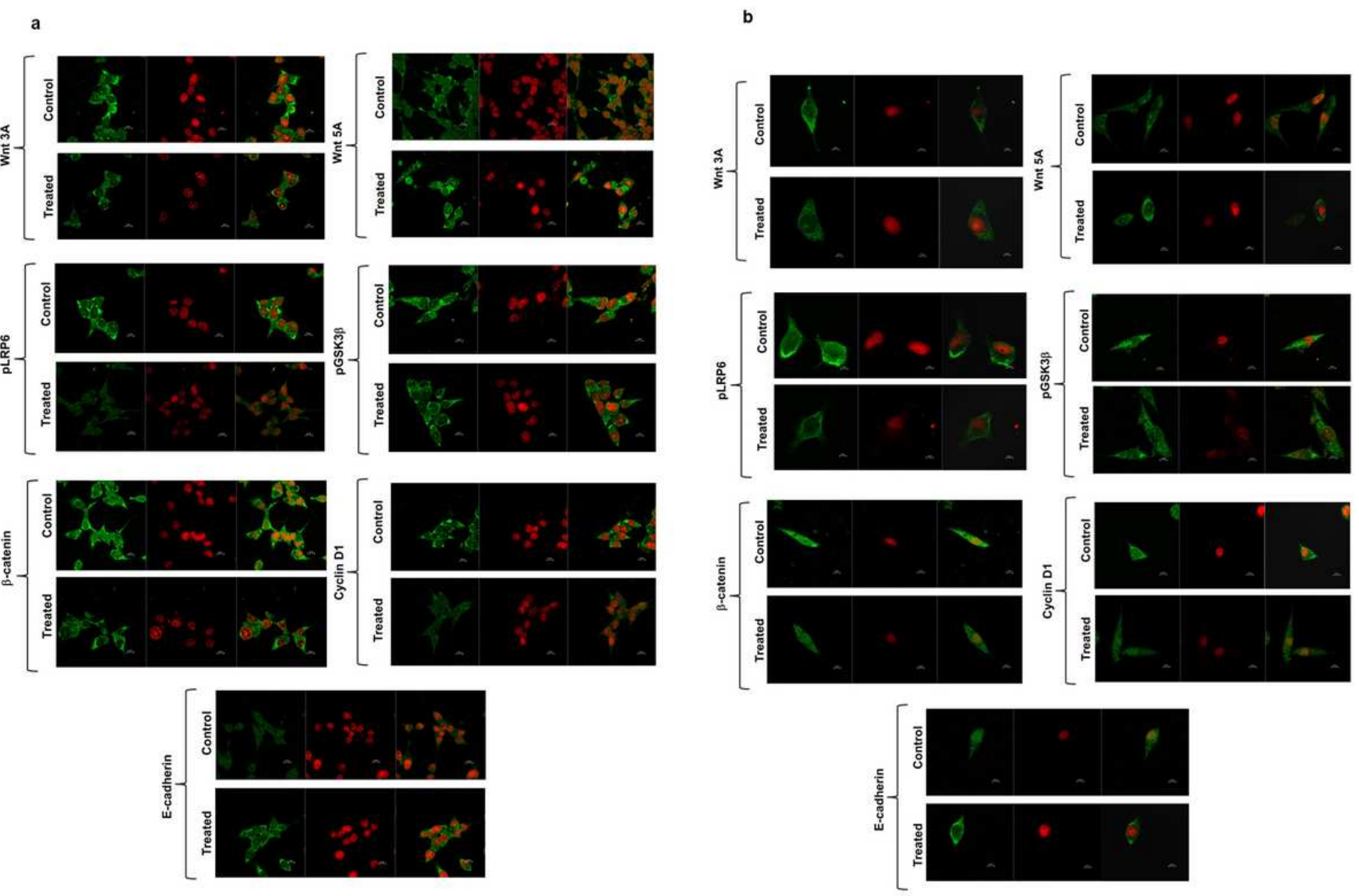

Figure 6

Study of the effect of M.Co on translational level expression of Wnt 3A, Wnt 5A, pLRP6, pGSK3, $\beta$ catenin, Cyclin D1 and E-cadherin by immunofluorescence staining. (a) Control and M.Co treated MCF-7 cells (b) Control and M.Co treated MDA-MB-231 cells 


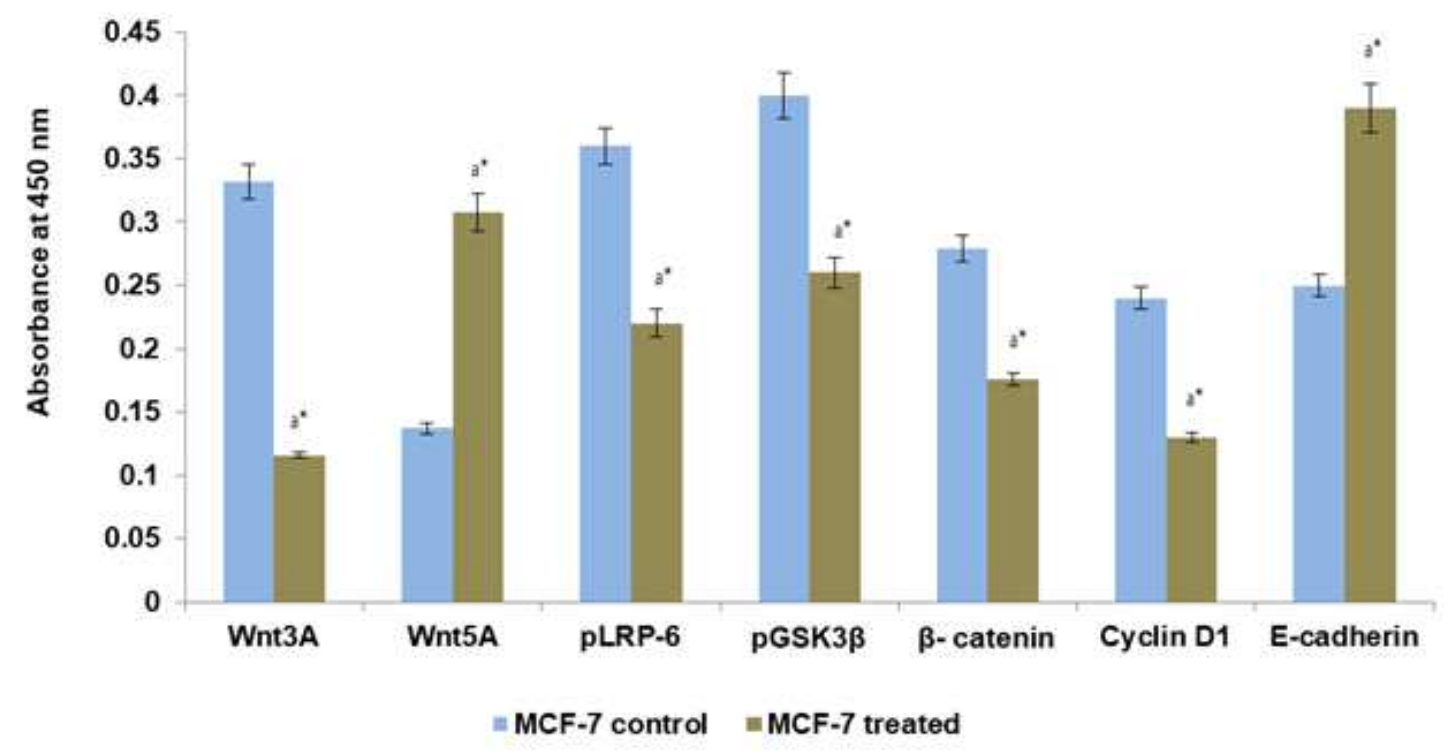

b

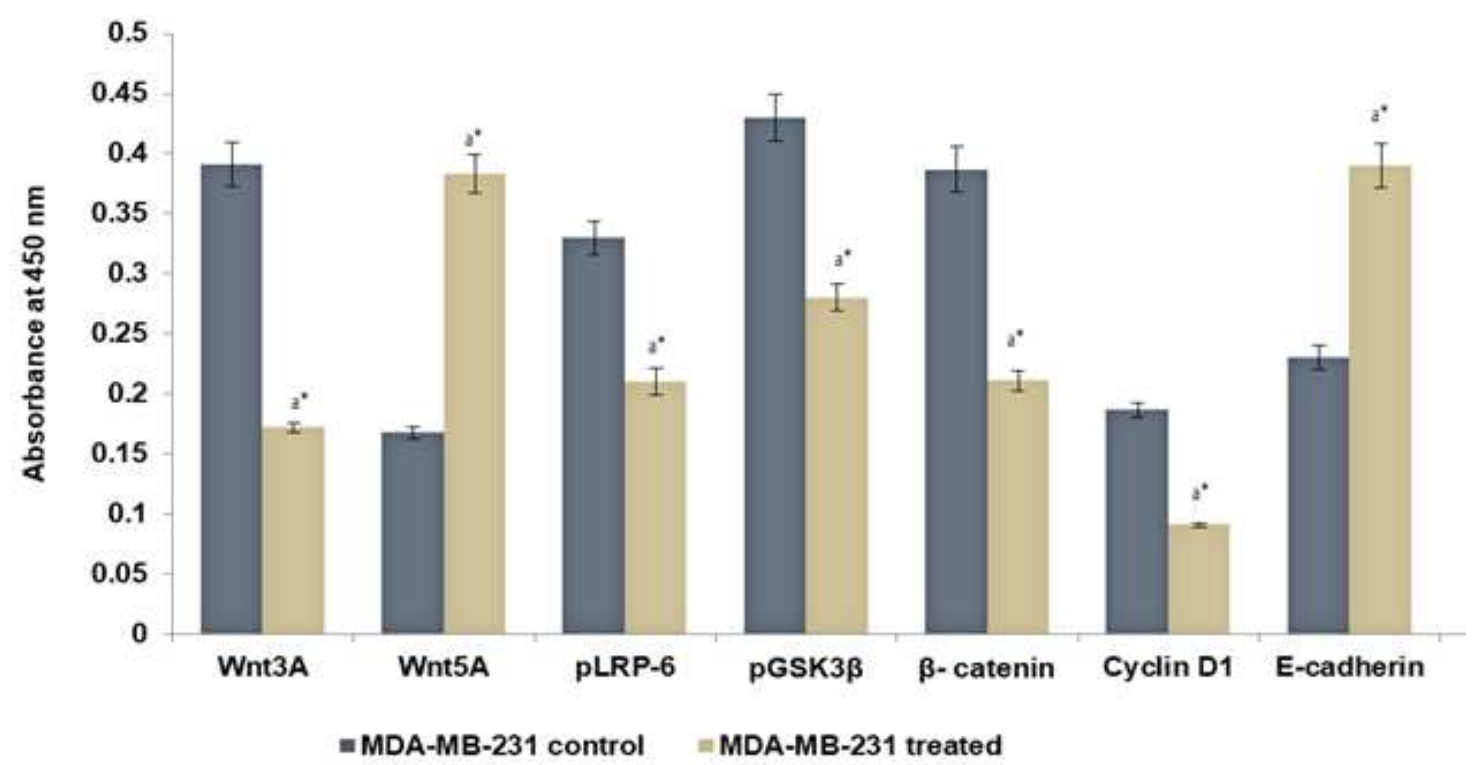

Figure 7

Study of effect of M.Co on translational level expression of Wnt 3A, Wnt 5A, pLRP6, pGSK3, $\beta$ catenin, Cyclin D1 and E-cadherin by indirect ELISA. Values are represented as absorbance at $450 \mathrm{~nm}$. (a) Control and M.Co treated MCF-7 cells (b) Control and M.Co treated MDA-MB-231 cells. Each value is expressed as mean \pm SD of three experiments. Statistical significance set at $P<0.01$. . Comparisons are made as a*control cells vs M.Co treated cells 